Journal of Applied Pharmaceutical Science Vol. 5 (08), pp. 026-033, August, 2015

Available online at http://www.japsonline.com

DOI: $10.7324 /$ JAPS.2015.50805

ISSN 2231-3354 (cc) BY-NC-SA

\title{
Screening, stability and antibacterial potential of rhamnolipids from Pseudomonas sp., isolated from hydrocarbon contaminated soil
}

\author{
Meganathan Velmurugan, Athmanathan Baskaran, Subbaraj Dinesh Kumar, Indrajith Sureka, Edward Arockia Raj \\ Jennifer Emelda, Karuppannan Sathiyamurthy* \\ Department of Bio-Medical Science,School of Basic Medical Sciences,BharathidasanUniversity, Tiruchirappalli - 620 024, Tamil Nadu, India.
}

\section{ARTICLE INFO \\ Article history: \\ Received on: 24/05/2015 \\ Revised on: $13 / 06 / 2015$ \\ Accepted on: 30/06/2015 \\ Available online: 28/08/2015}

\section{Key words:}

Hydrocarbon contaminated

soil, biosurfactant,

rhamnolipid, Pseudomonas

sp, antibacterial activity

\begin{abstract}
Surfactant plays an important role in industrial application such as oil recovery, lubricants and emulsifier. But chemical surfactants are toxic to human and other small animals. In recent years, biological based surfactants have gained increasing attention due to their ecofriendly in nature. The present study was focused to isolate biosurfactant producing bacteria, their stability and antibacterial ability from hydrocarbon contaminated and uncontaminated soil collected from different locations in Kanchipuram, Tamil Nadu, India. Biosurfactant producing bacteria were screened by following the haemolytic activity, drop collapsing test, emulsion against kerosene and was further confirmed through surface activity. The stability of the biosurfactant was determined by different physic-chemical conditions like $\mathrm{pH}$, temperature and salinity. A total of 37 strains were selected in three different samples based on cultural characters and finally only 7 strains were confirmed as positive for biosurfactant. Among these strain H11 was considered as potential based on emulsification index (44\%), surface activity (34.45 x 10-3 nm-1) and surface tension (23.17 x 10-3 nm-1) and was identified as Pseudomonas sp. The emulsification activity was stable at broad range of $\mathrm{pH}(4-12)$, temperature $\left(4-120^{\circ} \mathrm{C}\right)$ and salt concentration $(0$ $10 \%)$. The biosurfactant was further characterized in HPLC and one major peak was observed at a retention time of 2.033. The antibacterial activity of biosurfactant was high against gram positive pathogenic bacteria than gram negative bacteria. The rhamnolipid produced Pseudomonas sp. may be used as a tool to manage the oil pollution and to control the disease causing bacteria.
\end{abstract}

\section{INTRODUCTION}

Surfactants are chemical compounds that lower the surface tension of a liquid. Such compounds have a predilection for interfaces of dissimilar polarities (liquid-air or liquid-liquid) and are soluble in both organic (non-polar) and aqueous (polar) solvents. Bacterial production of biosurfactant was first demonstrated in 1941 by Bushnell and Hass. According to Amiriyan et al. (2004) biosurfactant are classified based on chemical nature viz., glycolipids, lipopeptides, lipoproteins, fatty acids, neutral lipids, phospholipids, polymeric and particulate biosurfactant. These properties originated from amphipathic structures, which comprises both hydrophilic (head) and hydrophobic groups (tail) (Calvo et al., 2004), and render surfactants capable of reducing surface and interfacial tensions and forming micro-emulsion (Desai and Banat, 1997).

\footnotetext{
* Corresponding Author

Karuppannan Sathiyamurthy, Department of Bio-Medical Science,

School of Basic Medical Sciences, Bharathidasan University,

Tiruchirappalli -620 024, Tamil Nadu, India

Email: ksathiyamurthy@yahoo.com
}

Biosurfactant are heterogeneous groups of secondary metabolites from a variety of microorganism with surface active properties (Chandrasekaran and Bemiller, 1980).

In the past decades, much attention has been intended for biosurfactant owing to their advantages such as biodegra dability, low toxicity, lower critical micelle concentration, environmental compatibility, higher specificity and better activity at extreme conditions like high temperature, high $\mathrm{pH}$ and high salinity (Banat, 1995; Cameotra et al., 1998; Ron and Rosenberg, 2001; VanHamme et al., 2006; Singh et al., 2013).

Rhamnolipids was first isolated from Pseudomonas aeruginosa and this compound are predominantly constructed from the union of one or two rhamnose sugar molecules and one or two beta hydroxyl (3-hydroxy) fatty acids. Rhamnolipid with one sugar molecule are referred to as mono-rhamnolipid (L-rhamnosyl- $\beta$ hydroxydecanoyl- $\beta$-hydroxydecanoate), while those with two sugar molecules are referred to as di-rhamnolipids (L-rhamnosylL-rhamnosyl- $\beta$-hydroxydecanoyl- $\beta$-hydroxydecanoate). 
The complete enzymatic synthesis of rhamnolipids, proceeds by sequential glycosyl transfer reaction, each reaction is catalyzed by specific rhamnosyl transferease and rhamnose acts as an efficient rhamnosyl donor in the synthesis of the rhamnolipid (Koch et al., 1991; Gunther et al., 2005). Biosurfactants having the surface properties make good candidate for enhanced oil recovery (EOR). The most effective biosurfactants reduce the surface tension (ST) of water from 72 dynes/cm to value of 25-30 dynes/cm (Georgiou et al., 1992; Rosenberg and Ron, 1999; Banat et al., 2000; Silva et al., 2014). Major functions of biosurfactants are foaming agents, solubilizers, wetting agents, emulsifiers, antimicrobial agents and mediators of enzyme action. On the other hand biosurfactants are also used in some cosmetic products like insect repellents, cleaners, lubricated condoms, baby products, shampoos etc., (Kosaric, 1992). The surfactin from Bacillus subtilis and rhamnolipid from Pseudomonas has a property of antimicrobial, antiadhesion, antibiofilm and detoxification of oil pollutant (Bechard et al., 1998; Mireles et al., 2001). Another most important application of biosurfactant is bioemlusifier, which stimulates oil production in marginal wells that have approached their economic limit (Banat, 1995; Ron and Rosenberg, 2001). Despite environmental application, biosurfactant have many biomedical application but only a very few work have been reported (Benincasa et al., 2004). Some biosurfactant are used as suitable alternative for synthetic medicines and antimicrobial agents and may be used as safe and effective therapeutic agents (Maier, 2003; Singh et al., 2007).

The increased need for the microbial biosurfactant has turned much attention among the researchers due to their versatile application. The main problem for the production of microbial surfactant in industry is high production cost. So, the demand of low cost raw material such as agro and industrial wastes are the best alternative sources for industrial production, these will compensates the right nutrient balance as an alternative for the substrate in the culture media (Makker and Cameotra, 1999). There are several renewable substrates from various sources, such as molasses (Makker and Cameotra, 1997), ground nut oil and corn steep liquor (Luna et al., 2013), potato processing effluents (Fox and Bala, 2000), olive and sunflower oil (Haba et al., 2000), cheese whey (Rodrigues et al., 2006), palm oil (Nawawi et al., 2010), motor lubricant oil and peanut oil (Thavasi et al., 2011) were used as a cheap sources for biosurfactant production. In this work, we evaluated the rhamnolipid producing Pseudomonas sp., from hydrocarbon contaminated soil, its stability and antibacterial activity.

\section{MATERIAL AND METHODS}

\section{Isolation of bacteria from soil and oil sample}

Soil and oil samples were collected from different locations in Kanchipuram town, Tamil Nadu, India. Soil samples were collected from hydrocarbon contaminated and agricultural fields, whereas oil samples like groundnut oil and 20W-40 oil were procured from extraction site and gasoline station respectively. All the samples were collected using new polyethylene container with utmost care to avoid contamination. The samples were transferred to the laboratory and microbiological analysis was carried out without any delay. $5 \mathrm{~g}$ of soil sample was added in a conical flask containing $50 \mathrm{ml}$ of tap water and incubated in a rotary shaker $(180 \mathrm{rpm})$ at room temperature for 21 days. Periodically $1 \mathrm{ml}$ of sample was drawn at regular interval and serially diluted in sterile saline. $0.1 \mathrm{ml}$ of diluted sample was spread plated onto nutrient agar medium and incubated for 7 days at room temperature (Bodour et al., 2003). For the isolation of bacteria from oil, $1 \mathrm{ml}$ of oil sample was added into $9 \mathrm{ml}$ of sterile saline and the mixture was placed on shaker for $1 \mathrm{~h}$ to produce well dispersed suspension (Amiriyan et al., 2004). Suspension was serially diluted in sterile saline, $0.1 \mathrm{ml}$ of sample was spread plated onto nutrient agar medium and incubated at room temperature for 7 days. After incubation morphologically different colonies were selected from all the plates, purified and screened for biosurfactant.

\section{Screening for biosurfactant producing strain Hemolytic activity}

In order to determine the hemolytic activity of pure isolates, $50 \mu \mathrm{l}$ of broth culture was spot inoculated on blood agar plates incorporated with 5\% human blood. Then the plates were incubated at room temperature (RT) for $24 \mathrm{~h}$ and clear zone was measured.

\section{Drop collapse test}

All the cultures that showed heamolysis were grown in mineral salt medium (MSM) supplemented with $0.1 \%$ of crude oil for $48 \mathrm{~h}$ at room temperature for drop collapse test. 96 well microtitre plate was rinsed with hot water (three times), 75\% ethanol (one time), distilled water (two times) and then air dried (Hamed et al., 2012). $2 \mu$ of crude oil was added to each well of a 96-well micro titer plate. The plate was equilibrated for $24 \mathrm{~h}$ at room temperature and then $5 \mu \mathrm{l}$ of culture supernatant was added to the surface of the oil. The shape of the drop on the oil surface was observed within 60 seconds. $1 \%$ Sodium dodecyl sulfate (SDS) and deionized water were used as positive and negative control. If the drop of the culture was collapsed then it was considered as positive and rest of them was noted as negative.

\section{Emulsification index}

To determine the emulsification index (EI), the positive strains obtained from the drop collapse test were cultured in MSM incorporated with $0.1 \%$ of crude oil for $48 \mathrm{~h}$ at room temperature (Cooper and Goldenberg, 1987). $2 \mathrm{ml}$ of kerosene was added with equal volume of cell free supernatant $8000 \mathrm{rpm}$ for $20 \mathrm{~min}$ and vortex at high speed for $2 \mathrm{~min}$, then the mixture was allowed to stand for $24 \mathrm{~h}$. After $24 \mathrm{~h}$, all the tubes were measured for the emulsification index by using the following formula Emulsification index $\left(\mathrm{E}_{24} \%\right)=$ height of the emulsion layer/total height of the mixture $\mathrm{x} 100$ 


\section{Blue agar method}

This is the specific screening test used to detect extra cellular rhamnolipid production. The biosurfactant producing isolates confirmed from primary tests were inoculated onto previously prepared blue agar plate and incubated at room temperature for 24-48 h. After incubation, the plates were visually examined for the presence of dark blue halos around the colonies. If the colonies were surrounded by dark blue halo the result was scored as positive. The rhamnolipid concentration is proportional to halo diameter.

\section{Quantitative test - drop weight method for the estimation of surface activity}

The potential strain was tested for the estimation of surface activity quantitatively by the drop weighed method as described by Sabesan et al. (2002). The cell suspension in MSM was centrifuged at $8000 \mathrm{rpm}$ for $20 \mathrm{~min}$ and the cell free supernatant was poured into a burette. The bottom of the burette was attached with glass tube via rubber tube. An empty preweighed beaker was placed under burette and the supernatant was released slowly drop by drop and 20 drops were collected into the beaker. This was weighed to determine the weight of 20 drops. The surface tension of the cell free supernatant was calculated by using the following formula

Mass of one drop $=($ Beaker + sample weight $)-$ empty beaker weight/number of drops

Surface tension $(\mathrm{T})=\mathrm{Mg} / \pi \mathrm{r} \times 10^{-3} \mathrm{x} \mathrm{nm}^{-1}$

Where, $\mathrm{M}$ - Mass of one drop, $\mathrm{g}$ - Gravity, $\mathrm{r}$ - Radius of glass tube

Surface activity of the each isolate was calculated by the following formula

Surface activity $=$ surface tension of unionoculated medium surface tension of supernatant.

\section{Production and extraction of biosurfactant in MSM}

$1 \mathrm{ml}$ of overnight nutrient broth grown culture was inoculated into $250 \mathrm{ml}$ conical flask containing $100 \mathrm{ml}$ of MSM (Cameotra and Makkar, 1998). Then the flask was incubated with $180 \mathrm{rpm}$ for $48 \mathrm{~h}$ at $37^{\circ} \mathrm{C}$. After $48 \mathrm{~h}$ of incubation the cell free supernatant was obtained by centrifugation at $8000 \mathrm{rpm}$ for 20 min. The supernatant was then precipitated by means of acidification $(\mathrm{pH} 2)$ with $6 \mathrm{~N}$ hydrochloric acid and left for overnight at $4^{\circ} \mathrm{C}$. Afterwards, the precipitate was centrifuged at $10000 \mathrm{rpm}$ for $10 \mathrm{~min}$ at $4^{\circ} \mathrm{C}$. Then the supernatant was discarded and the precipitate was dissolved with $0.05 \mathrm{M}$ bicarbonate solution $\left(\mathrm{pH} \mathrm{8.6)}\right.$ and centrifuged again at $15000 \mathrm{rpm}$ for $20 \mathrm{~min}$ at $4^{\circ} \mathrm{C}$. Following centrifugation, precipitate was suspended in chloroform: methanol (2:1) mixture and centrifuged at $10000 \mathrm{rpm}$ for $5 \mathrm{~min}$. After that three phases were formed, the upper and middle phase containing the solvent, the lower phase containing the biosurfactant and finally solvent was evaporated. The concentrated biosurfactant was extracted three times with pure methanol. The crude biosurfactant was collected and used for further chromatographic analysis.

\section{Production and extraction of biosurfactant in MSM with molasses and glucose}

The potential biosurfactant producing strain was inoculated into MSM supplemented with glucose (2\%) and incubated at RT for $48 \mathrm{~h}$ at $180 \mathrm{rpm}$ in $250 \mathrm{ml}$ conical flask. A seed culture was prepared in nutrient broth, and the culture was inoculated in $250 \mathrm{ml}$ conical flask containing $100 \mathrm{ml}$ MSM supplemented with molasses $(2 \%)$ as a carbon source and incubated at RT at $180 \mathrm{rpm}$ for $48 \mathrm{~h}$ (Rodrigues et al., 2006).

\section{Stability of biosurfactant}

Stability studies were performed with crude biosurfactant (1000 mg/l). Each $10 \mathrm{ml}$ of crude biosurfactant solution was maintained in a wide range of $\mathrm{pH}(4,6,8,10$ and 12) in $1 \mathrm{~h} 180$ rpm in a rotary shaker and emulsification index was calculated. To evaluate the temperature stability of biosurfactant, the samples were kept at $4, \mathrm{RT}, 40,60,80$ and $120^{\circ} \mathrm{C}$ for $1 \mathrm{~h}$ and cooled to room temperature after the emulsification index was determined. The effect of salinity was investigated on biosurfactant by dissolving crude biosurfactant with various concentrations of sodium chloride $(0,2.5,5,7.5$ and $10 \%)$.

\section{Thin layer chromatography}

Partial purification of crude biosurfactant was done by using thin layer chromatography on silica gel plate as described by Parra et al. (1989).

\section{Column chromatography for the purification of the extract}

The partially purified yellow colored rhamnolipid was dissolved in $1 \mathrm{ml}$ of chloroform and subjected to column chromatography. For the purification of the mono-rhamnolipid, the glass column (Length $-20 \mathrm{~cm}$; internal diameter $-2 \mathrm{~cm}$ ) was dry packed with silica gel 60 and eluted with chloroform: methanol (10:1). After settling and equilibration, the extract dissolved in 1 $\mathrm{ml}$ chloroform, was gradually poured onto the column (Zhang and Miller, 1995). The eluent was collected as different fraction at one minute interval. Each fraction was further inspected for surface activity using drop collapse method to identify the fraction containing active compounds. The entire fractions were tested by drop collapse method to identify the active fraction.

\section{Assessment of active column chromatographic fraction using High Performance Liquid Chromatography (HPLC)}

The purity of biosurfactant in pooled fraction of column chromatography was assessed using high performance liquid chromatography (Lin et al., 1998). The active compound was further purified by using chloroform: methanol (9:1) by Waters Breeze HPLC equipped with $\mathrm{C}_{18}$ reverse phase column and UV wavelength detector set at $260 \mathrm{~nm}$ and $\lambda \max$ of the sample determined by UV-Vis spectral analysis.

\section{Antimicrobial activity}

The crude biosurfactant was dissolved in methanol (1 $\mathrm{mg} / \mathrm{ml})$, sterilized by syringe filter $(0.22 \mu \mathrm{m})$ and kept in a sterile 
glass tube. This stock was used for antimicrobial activity against various human bacterial pathogens like Escherichia coli, Pseudomonas aeruginosa, Klebseilla sp., Staphylococcus aureus and Bacillus subtilis.

\section{Disc diffusion test}

The susceptibility of human pathogens was tested against biosurfactant in the Muller Hinton Agar (MHA) plate (Hi-Media, India) by adopting disc diffusion test. All the test strains were inoculated into nutrient broth (NB) medium, incubated at $37^{\circ} \mathrm{C}$ for overnight. The OD $480 \mathrm{~nm}$ was adjusted to $0.1\left(10^{8} \mathrm{CFU} / \mathrm{ml}\right)$ according to McFarland standard (CLSI, 2005). Using sterile cotton swab, strains were swabbed onto the pre-solidified MHA plates and allowed to dry. Sterile discs were impregnated with the purified biosurfactant stock solution and dried. One disc was impregnated with methanol as negative control. Disc was placed onto the MHA plates with $20 \mathrm{~mm}$ distance. All the plates were incubated at $37^{\circ} \mathrm{C}$ for $24 \mathrm{~h}$ and clearance zone was observed after $24 \mathrm{~h}$.

\section{Well diffusion method}

MHA plates were prepared and swabbed with the above pathogens. Using a sterile cork borer, well was made and $50 \mu 1$ of the purified biosurfactant stock solution was added to the wells and incubated at $37^{\circ} \mathrm{C}$ for $24 \mathrm{~h}$. After incubation, the zone of clearance was measured.

\section{Identification of the potent strain}

The potential strain was characterized by standard bacteriological procedure through biochemical test and the results were interpreted with Bergey's manual for systematic bacteriology to identify the organism.

\section{RESULTS}

\section{Isolation and screening of biosurfactant producing bacteria from soil and oil}

For the screening of biosurfactant producers, soil and oil samples were collected from different locations in Kanchipuram town, Tamil Nadu, India. Total culturable bacteria were fluctuated from 4.4 to $6.6 \times 10^{6} \mathrm{CFU} / \mathrm{g}$ in soil sample and 2.5 to $4.3 \times 10^{3}$ $\mathrm{CFU} / \mathrm{ml}$ in oil sample (Table 1). A total of 37 isolates were selected and isolated from all the samples to screen biosurfactant activity and it was found that only 22 strains were positive in primary screening through hemolytic activity in blood agar plate. All the strains positive for hemolytic activity were further screened for drop collapse test to confirm biosurfactant producers. The results revealed that only 7 (31.8\%) strains confirmed as potent biosurfactant producers. (Table 1) Among the 7 strains, the strain $\mathrm{H} 11$ was found high potent strain for biosurfactant activity based on emulsification (44\%), surface activity $\left(34.45 \times 10^{-3} \mathrm{~nm}^{-1}\right)$ and surface tension $\left(23.17 \times 10^{-3} \mathrm{~nm}^{-1}\right)$ (Table $2 \& 3$ ). Further, biosurfactant was characterized in blue agar plate and the dark blue halo was observed around the colonies. Hence, strain $\mathrm{H} 11$ was considered as positive for rhamnolipid.

\section{Production and extraction}

The strain H11 was grown in MSM medium containing $2 \%$ glucose and molasses for biosynthesis of biosurfactant. The amount of biosurfactant was noticed as $4.0 \mathrm{mg} / 100 \mathrm{ml}$ and 5.8 $\mathrm{mg} / 100 \mathrm{ml}$ in glucose and molasses respectively. This biosurfactant was reconfirmed through drop collapse and surface tension test and the surface tension was $23.17 \times 10^{-3} \mathrm{~nm}^{-1}$ in glucose $23.14 \times 10^{-3} \mathrm{~nm}^{-1}$ in molasses.

Table 1: Enumeration of total viable counts and isolation of biosurfactant producing organism in different samples.

\begin{tabular}{|c|c|c|c|c|c|}
\hline Sample & $\begin{array}{c}\text { Total number of } \\
\text { colonies (CFU/ml) }\end{array}$ & $\begin{array}{l}\text { No. of isolates } \\
\text { selected }\end{array}$ & Positive for Hemolysis & $\begin{array}{l}\text { Positive for Drop } \\
\text { collapse }\end{array}$ & $\begin{array}{c}\text { Number of biosurfactant } \\
\text { producers }\end{array}$ \\
\hline Soil Hydro carbon contaminated & $4.4 \times 10^{6}$ & 12 & $8(66.6 \%)$ & $3(37.5 \%)$ & $3(25 \%)$ \\
\hline Agricultural field Oil & $6.6 \times 10^{6}$ & 10 & $6(60 \%)$ & $2(33.3 \%)$ & $2(20 \%)$ \\
\hline Oil extraction site & $2.5 \times 10^{3}$ & 6 & $3(50 \%)$ & $1(33.3 \%)$ & $1(16.6 \%)$ \\
\hline Mechanic shed & $4.3 \times 10^{3}$ & 9 & $5(55.5 \%)$ & $1(20 \%)$ & $1(11.1 \%)$ \\
\hline
\end{tabular}

Table 2: Emulsification activity of the biosurfactant with kerosene

\begin{tabular}{ccc}
\hline Strain name & Emulsification index $\left(\mathbf{E}_{24}\right)$ \\
\hline O1 & $10 \%$ \\
O9 & $6.6 \%$ \\
H2 & $11 \%$ \\
H4 & $11 \%$ \\
H11 & $44 \%$ \\
H17 & $42 \%$ \\
H21 & $20 \%$ \\
\hline
\end{tabular}

Table 3: Quantitative measurement of surface activity and surface tension by drop collapse weight method

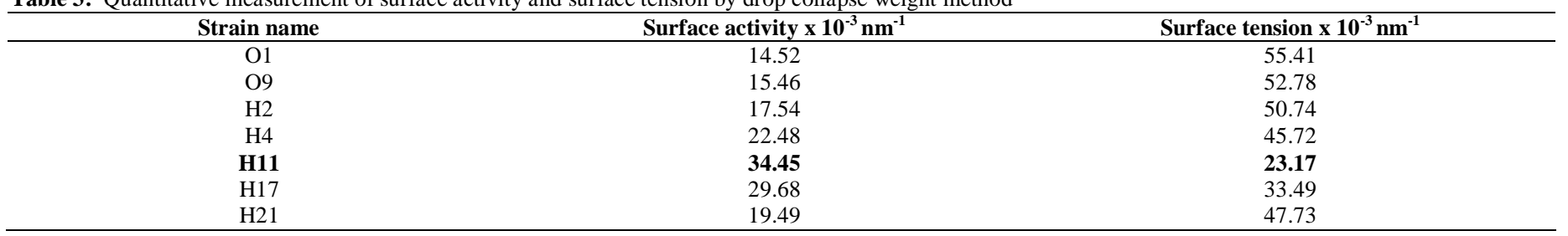




\section{Stability of biosurfactant}

The application of biosurfactant in several fields depends on their stability at different $\mathrm{pH}$, temperature and salinity. In our observation, emulsification index of the biosurfactant was stable at neutral $\mathrm{pH}$. In acidic and alkaline condition the stability was fluctuated between 4 and 12 (Fig 1-A). The stability of biosurfactant in different temperatures was shown in Fig 1-B and found to withstand even up to $120^{\circ} \mathrm{C}$ with optimum activity at $60^{\circ} \mathrm{C}$. Similarly, in different salt concentration the stability of biosurfactant was constant at $2.5 \% \mathrm{NaCl}$ and the stability was noticed up to $10 \% \mathrm{NaCl}$ in lab condition (Fig $1-\mathrm{C})$.

\section{Purification of compound by chromatography technique}

The biosurfactant was partially purified from crude extract with chloroform:methanol:water by thin layer chromatography. Two spots were observed with spot $1 \mathrm{R}_{\mathrm{f}}$ value of 0.56 and spot $2 \mathrm{R}_{\mathrm{f}}$ value of 0.63 . Spot 1 was confirmed by drop collapse and subjected to column and HPLC chromatographical techniques. The fraction was collected and tested for drop collapse assay (data not shown) and only one fraction corresponding to the peak retention time of $2.033 \mathrm{~min}$ in HPLC to be active and showed the high emulsification activity (Fig 2).

\section{Antimicrobial activity}

Antimicrobial activity of purified biosurfactant showed broad spectrum of activity against the pathogenic bacteria tested. The result showed that the highest activity against Bacillus subtilis (11 $\mathrm{mm}$ in disc and $12 \mathrm{~mm}$ in well) followed by Staphylococcus aureus and Escherichia coli. The least activity was observed against Pseudomonas aeruginosa $(8 \mathrm{~mm}$ in disc and 9 $\mathrm{mm}$ in well) (Table 4).

Table 4: Antimicrobial activity by disc and well diffusion technique.

\begin{tabular}{lcc}
\hline \multicolumn{1}{c}{ Test organism } & Disc diffusion $(\mathbf{m m})$ & Well diffusion $(\mathbf{m m})$ \\
\hline Staphylococcus aureus & 10 & 11 \\
Bacillus subtilis & 11 & 12 \\
Escherichia coli & 10 & 9 \\
Pseudomonas aeruginosa & 8 & 9 \\
Klebseilla sp. & 9 & 10 \\
\hline
\end{tabular}

The potential strain was identified as Pseudomonas sp., based on cultural characteristics and biochemical tests.
A

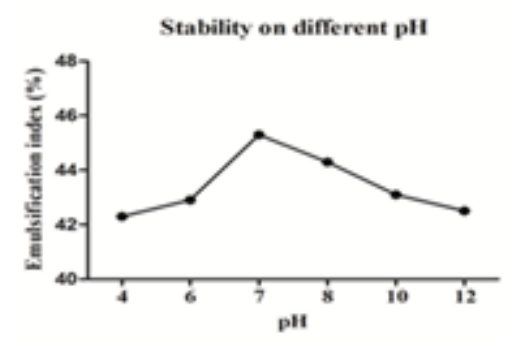

B

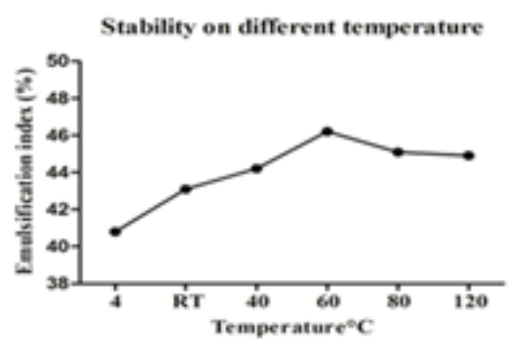

$\mathrm{C}$

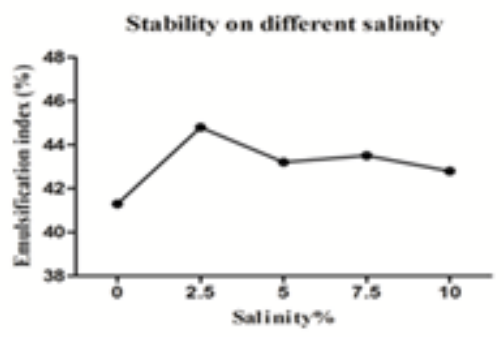

Fig. 1: Effect of $\mathrm{pH}(\mathrm{A})$, temperature (B) and salinity (C).

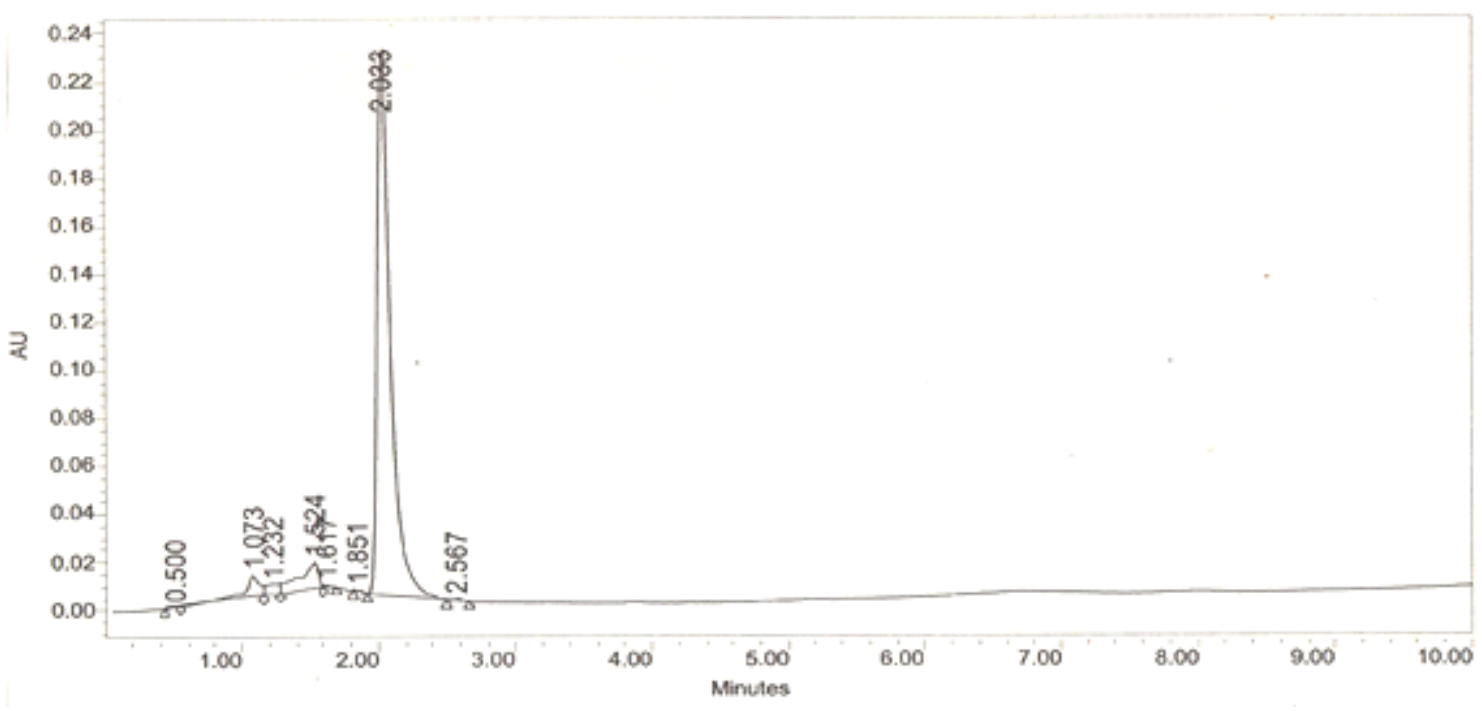

Fig. 2: RP-HPLC Chromatogram of rhamnolipid at 260nm. 


\section{DISCUSSION}

In present days, surfactant plays a very significant role in food industry, bioremediation and medical application. So, researchers are paying attention on screening and isolation of biosurfactant from natural environment. A total of seven biosurfactant producing isolates were obtained from soil and oil samples. Bodour et al. (2003) obtained 45 biosurfactant producing isolates from hydrocarbon contaminated South Western soils of Arizona and most of the surfactant producing isolates was tending from contaminated and co-contaminated soil. Amiriyan et al. (2004) reported 11 biosurfactant producers from Iranian oil reservoirs. The present findings are in accordance with the findings of Bodour et al. (2003) and Amiriyan et al. (2004). However, findings of Ramesh et al. (2010) was contrary from this study who reported biosurfactant only in hydrocarbon contaminated soil. But in this study, biosurfactant produced organisms was isolated both in contaminated and uncontaminated soil. This might be due to the nature of the soil and nutrient content present in it. Out of 37 strains, only 22 strains were positive for hemolytic activity. The hemolysis was used widely to screen biosurfactant in microbes (Banat 1993; Carrillo et al., 1996; Yonebayashi et al., 2000). The hemolytic activity of biosurfactant was first studied by Bernheimer and Avigad (1970) in B. subtilis. Carrillo et al. (1996) found an association between hemolytic activity and surfactant production, and they recommended the use of blood agar lysis as a primary screening. Bodour et al. (2003) used drop collapse assay for screening surfactant producing isolates, they emulsified the coated oil in culture broth and made micro emulsion. Because of the formation of micro emulsions, the culture drops collapsed in coated oil. No other isolates except biosurfactant producing organisms, form micro emulsion in this specific screening test. In the present study, 22 strains were screened based on hemolysis, and only 7 strains were confirmed through drop collapse assay. Therefore, the results obtained in this study are more valuable in application point of view.

For the detection of potential strain, Amiriyan et al. (2004) measured the $\mathrm{E}_{24}$ value of isolates showed over $60 \%$ emulsification activity with kerosene. Aparna et al. (2012) used different hydrocarbon and vegetable oil for emulsification activity. They found vegetable oil give more emulsification when compare to hydrocarbons. Sunflower oil produces $84.0 \%$, kerosene $67.5 \%$ and benzene produces $33.8 \%$. Thavasi et al. (2011) isolated $P$. aeruginosa from sea water in Tuticorin harbor area used different hydrocarbon and Triton X-100. Maximum emulsification showed in Triton X-100 against waste motor lubricant oil. However, in the present study, the potential isolate showed only $44 \%$ emulsification. This might be due to poor emulsification ability with kerosene. The isolates may have the ability to emulsify more when using other suitable hydrocarbons or vegetable oil than kerosene. Siegmund and Wagner (1991) and Deziel et al. (1996) who recommended the blue agar plate technique for screening anionic glycolipid surfactant. Rhamnolipids are one of the members of anionic glycolipid biosurfactants. They form an insoluble ion pair with the cationic tenside cetyl trimethyl ammonium bromide and the basic dye methylene blue, which are included in mineral agar plates. In these study also dark blue halos was noticed in potential isolates around the colonies. This confirmed the surfactant produced by the potential strain as rhamnolipids. Production of biosurfactant is not economically impressive. To reduce the production cost of biosurfactants, various agro-industrial wastes are recommended by Maneerat (2005). Molasses have tremendous potential to support microbial growth and surfactant production. Patel and Desai (1997) used molasses for biosurfactant production from $P$. aeruginosa GS3 and yield was $0.25 \mathrm{~g} / \mathrm{l}$. Molasses is a cheap and easily available in India and it contains more than 50\% carbon. Aparna et al. (2012) studied the production of biosurfactant by using different carbon sources like molasses (4.97 g/l), glycerol (4.14 g/l), coconut oil cake $(4.38 \mathrm{~g} / \mathrm{l})$, orange peelings $(3.24 \mathrm{~g} / \mathrm{l})$ and whey $(4.09 \mathrm{~g} / \mathrm{l})$. They also attempted without carbon source and the yield was noted as $0.22 \mathrm{~g} / \mathrm{l}$. In the present study the amount of biosurfactant produced was $0.58 \mathrm{~g} / \mathrm{l}$ and $0.40 \mathrm{~g} / \mathrm{l}$ in molasses and glucose at a concentration of $20 \mathrm{~g} / \mathrm{l}$. This was higher when compared to Patel and Desai (1997) and lower to Aparna et al. (2012).

Sriram et al. (2011) who found the stability of biosurfactant from $B$. cereus NK1 (GU 167978) in alkaline $\mathrm{pH}$. They also noticed the biosurfactant withstand at $120^{\circ} \mathrm{C}$ for $1 \mathrm{~h}$ and resisted at $15 \% \mathrm{NaCl}$ concentration. Luna et al. (2013) reported Candida sphaerica in the cell free broth stable at wide range of $\mathrm{pH}$ (2-12), stable $1 \mathrm{~h}$ at extreme temperature $120^{\circ} \mathrm{C}$ and withstand $\mathrm{NaCl}$ concentration of $10 \%$. In the present study, the biosurfactant produced by Pseudomonas sp., had the capability of withstand at wide elevated $\mathrm{pH}$ ranges, and not in acidic condition, because in acidic condition biosurfactant can normally precipitated. However, alkaline condition is very useful to treat the oil spilling in marine environment extreme temperature and high salinity. This gives a better idea to use biosurfactant in an extreme condition prevailing in the environment. Crude compound of biosurfactant produced brown spot on the TLC plate and the $\mathrm{R}_{\mathrm{f}}$ value was calculated as 0.59 (Parra et al., 1989). Same procedure was followed by Zhang and Miller in 1994 , the $R_{\mathrm{f}}$ value was calculated as $0.70 . \mathrm{R}_{\mathrm{f}}$ value noted as 0.52 and 0.69 in the crude extract biosurfactant visualized under UV-illuminator by Sriram et al. (2011). In the present study, two spots were observed and the $\mathrm{R}_{\mathrm{f}}$ value was calculated as 0.56 and 0.68. This is in agreement with the findings of previous studies reported elsewhere. Further purification of compound was achieved by column chromatography. Stanghellini (1997) reported the purification of rhamnolipid in column chromatography by using the solvent system chloroform: methanol in the concentration of 9:1 and there was a contamination with dirhamnolipid. In the present study, compound from the column chromatography was further purified by reverse phase HPLC. This was a better purified compound compared to the previous study. Zgola-Grzeskowiak and Kaczorek isolated rhamnolipid using different solvent system. They tested the mono-rhamnolipid Rha C10C10 and di-rhamnolipid RhaRhaC10C10. They identified different types of mono and di-rhamnolipid by reverse phase 
HPLC, and had a retention time of 1.42 in mono-rhamnolipid and retention time of 1.02 in di-rhamnolipid. However, in our study only one major peak was observed with the retention time of 2.033 and this was confirmed as mon-orhamnolipid. Abalos et al. (2001) reported that mixture of rhamnolipid produced by strain M7 $P$. aeruginosa AT10 was active against wide range of microbes including gram positive and gram negative organisms. Das et al. (2008) found that surfactin produced by B. circulans had antimicrobial activity, it active against most gram positive bacteria than gram negative bacteria. Kiran et al. (2010) also found that column fraction having the high activity comparing to ethyl acetate extract and supernatant, however it has less activity against the gram positive bacteria Bacillus sp., yeast of $C$. albicans followed by $K$. pneumonia. Similar findings were also evident in the present study and it was found that antimicrobial activity was high against gram positive organisms compared to gram negative one.

\section{CONCLUSION}

Pseudomonas spp., isolated from the hydrocarbon contaminated soil a potent biosurfactant producer. Fascinatingly, biosurfactant was stable at wide $\mathrm{pH}$ ranges, temperature and $\mathrm{NaCl}$ concentration. At the same time it has antimicrobial activity against the various pathogens. Hence, we suggested that the biosurfactant produced by Pseudomonas sp., will be an immense useful both environmental as well as biomedical application.

\section{REFERENCES}

Abalos A, Pinazo A, Infante MR, Casals M, Garcia F, Manresa A. Physicochemical and Antimicrobial Properties of New Rhamnolipids Produced by Pseudomonas aeruginosa AT10 from Soybean Oil Refinery Wastes. Langmuir, 2001; 17(5):1367-1371.

Amiriyan A, Mazarheri Assadi M, Saggadian VV, Noohi A. Bioemulsion production by Iranian oil reservoirs microorganisms. Iranian J Health Sci Eng, 2004; 1(2):28-35.

Aparna A, Srinikethan G, Smitha H. Production and characterization of biosurfactant produced by a novel Pseudomonas sp. 2B. Colloids and Surfaces B: Biointerfaces, 2012; 95:23-29.

Banat IM. The isolation of a thermophilic biosurfactant producing Bacillus sp. Biotechnology letters. 1993; 15(6):591-594.

Banat IM. Charaterization of biosurfactants and their use in pollution removalstate of the art. Acta Biotechnol, 1995; 15:251-267.

Banat IM, Makkar RS, Cameotra SS. Potential commercial applications of microbial surfactants. Appl Microbiol Biotechnol, 2000; 53:495-508.

Bechard J, Eastwell KC, Sholberg PL, Mazza G, Skura B. Isolation and partial chemical characterization of an antimicrobial peptide produced by a strain of Bacillus subtilis. J Agric Food Chem, 1998; 46:5355-5361.

Benincasa M, Abalos A, Oliveira I, Manresa A. Chemical structure, surface properties and biological activities of the biosurfactant produced by Pseudomonas aeruginosa LB1 from soapstock. Antonie Van Leeuwenhoek, 2004; 85:1-8.

Bernheimer AW, Avigad LS. Nature and properties of a cytolytic agent produced by Bacillus subtilis. Journal of General Microbiology. 3:361-369.

Bodour, A.A., Drees, K.P., and Maier, R.M. 2003. Distribution of biosurfactant-producing bacteria in undisturbed and contaminated arid southwestern soils. Appl Environ Microbiol, 1970; 69(6):3280-3287.
Bushnell LD, Haas HF. The utilization of certain hydrocarbons by microorganisms. J Bacteriol, 1941; 41:653-673.

Calvo C, Toledo FL, González-López J. Surfactant activity of a naphthalene degrading Bacillus pumilus strain isolated from oil sludge. J Biotechnol, 2004; 109:255-262.

Cameotra SS, Makkar RS. Synthesis of biosurfactants in extreme conditions, Appl Microbiol Biotechnol 1998; 50:520-529.

Carrillo PG, Mardaraz C, Pitta-Alvarez SI, Giulietti AM. Isolation and selection of biosurfactant-producing bacteria. World $\mathrm{J}$ Microbiol Biotechnol, 1996; 12(1):82-84.

Chandrasekaran EV, Bemiller JN. 1980. Constituent analysis of glucosamonoglucans. In: Wrhiste L. and Wolfrom M.L. (eds), Methods in Carbohydrate Chemistry Vol. iii. Academic Press, New York. 89-97.

Clinical and Laboratory Standards Institute, CLSI 2005. Performance standards for antimicrobial susceptibility testing. CLSI approved standard M100-S15. Wayne. PA

Cooper DG, Goldenberg BG. Surface-active agents from two Bacillus species. Appl Environ Microbiol, 1987; 53(2):224-229.

Das P, Mukherjee S, Sen R. Antimicrobial potential of a lipopeptide biosurfactant derived from a marine Bacillus circulans. J Appl Microbiol, 2008; 104(6):1675-1684.

Desai JD, Banat IM. Microbial production of surfactants and their commercial potential. Microbiol Mol Biol Rev, 1997; 61:47-64.

Deziel E, Paquette G, Villemur R, Lepine F, Bisaillon J. Biosurfactant production by a soil pseudomonas strain growing on polycyclic aromatic hydrocarbons. Appl Environ Microbiol, 1996; 62(6): 1908-1912.

Fox SL, Bala GA. Production of surfactant from Bacillus subtilis ATCC 21332 using potato substrates. Bioresource Technology, 2000; 75:235-240

Georgiou G, Lin SC, Sharma MM. Surface-active compounds from microorganisms. Biotechnology, 1992; 10:60

Gunther NW, Nunez A, Fett W, Solaiman DK. Production of rhamnolipids by Pseudomonas chlororaphis, a nonpathogenic bacterium. Appl Environ Microbiol, 2005; 71(5):2288-2293.

Haba E, Espuny MJ, Busquets M, Manresa A. Screening and production of rhamnolipids by Pseudomonas aeruginosa 47T2 NCIB 40044 from waste frying oils. J Appl Microbiol, 2000; 88:379-387.

Hamed SB, Smii L, Ghram A, Maaroufi A. Screening of potential biosurfactant-producing bacteria isolated from seawater biofilm. Af J Biotechnol, 2012; 11(77):14153-14158.

Holt JG, Krieg NR, Sneath PHA, Staley JT, Williams ST. 1994. Bergey's manual of determinative bacteriology $1-4$. Williams and Wilkins. Baltimore, USA.

Kiran GS, Sabarathnam B, Selvin J. Biofilm disruption potential of a glycolipid biosurfactant from marine Brevibacterium casei. FEMS Immunol Med Microbiol, 2010; 59(3):432-438.

Koch AK, Kappeli O, Fiechter A, Reiser J. Hydrocarbon assimilation and biosurfactant production in Pseudomonas aeruginosa mutants. J Bacteriol, 1991; 173(13):4212-4219.

Kosaric N. Biosurfactants in industry. J Am Oil Chem Soc, 1992; 64:731-1737.

Lin SC, Sharma MM, Georgiou G. Production and deactivation of biosurfactant by Bacillus licheniformis JF-2. Biotechnology progress, 1993; 9(2):138-145.

Luna JM, Rufino RD, Sarubbo LA, Campos-Takaki GM. Characterisation, surface properties and biological activity of a biosurfactant produced from industrial waste by Candida sphaerica UCP0995 for application in the petroleum industry. Colloids and Surfaces B: Biointerfaces, 2013; 102:202- 209.

Maier RM. Biosurfactants: evolution and diversity. Adv Appl Microbiol, 2003; 52:101-121.

Makkar RS, Cameotra SS. Biosurfactant production by a thermophilic Bacillus subtilis Strain. J Ind Microbiol Biotechnol, 1997; $18: 37-42$

Makkar RS, Cameotra SS. Biosurfactant Production by Microorganisms on Unconventional Carbon Sources. J Surfact Deterg, $1999 ; 2(2): 237-241$ 
Maneerat S. Production of biosurfactants using substrates from renewable-resources. Songklanakarin J Sci Technol, 2005; 27(3): 675-683.

Mireles JR, Toguchi A, Harshey RM. Salmonella enterica Serovar Typhimurium Swarming Mutants with Altered Biofilm-Forming Abilities: Surfactin Inhibits Biofilm Formation. J Bacteriol, 2001; 183(20):5848-5854.

Nawawi W, Jamal P, Zahangir A. Utilization of sludge palm oil as a novel substrate for biosurfactant production. Bioresource Technology, 2010; 101:9241-9247.

Parra JL, Guinea J, Manresa MA, Robert M, Mercade ME, Comelles F, Bosch MP. Chemical characterization and physicochemical behavior of biosurfactants. J Am Oil Chem Soc, 1989; 66(1):141-145.

Patel RM, Desai AJ. Biosurfactant production by Pseudomonas aeruginosa GS3 from molasses. Lett Appl Microbiol, 1997; 25(2):91-94.

Ramesh B, Kavitha K, Suresh G, Usharani B, Ravichandran N, Vijaiyansiva G. Studies on Distribution of Biosurfactant Producing Bacteria in Contaminated and Undisturbed Soils of Kanchipuram. Aus J Basic Appl Sci, 2010, 4(9):4429-4434

Rodrigues LR, Teixeira JA, Oliveira R. Low-cost fermentative medium for biosurfactant production by probiotic bacteria. Biochemical Engineering Journal, 2006; 32:135-142.

Ron EZ, Rosenberg E. Natural roles of biosurfactants. Environ. Microbiol. 2001; 3(4):229-236.

Rosenberg E, Ron EZ. High and low molecular mass microbial surfactants. Appl Microbiol Biotechnol, 1999; 52:154-162.

Sabesan R, Dhanalakshmi A, William A, Thangaraj K. 2002. Text book of allied physics. Popular book depot. Second print. 65-68.

Siegmund I, Wagner F. New method for detecting rhamnolipids excreted by Pseudomonas species during growth on mineral agar. Biotechnology Techniques, 1991; 5(4): 265-268.

Silva NMPR, Rufino RD, Luna JM, Santos VA, Sarubbo LA. Screening of Pseudomonas species for biosurfactant production using lowcost substrates. Biocatalysis and Agricultural Biotechnology, 2014; 3(2):132-139.

Singh A, Van Hamme JD, Ward OP. Surfactants in microbiology and biotechnology: Part 2. Application aspects. Biotechnol Adv, 2007; 25:99-121.

Singh SP, Bharali P, Konwar BK. Optimization of nutrient requirements and culture conditions for the production of rhamnolipid from Pseudomonas aeruginosa (MTCC 7815) using Mesua ferrea seed oil. Indian J Microbiol, 2013; 53(4):467-476.
Sriram MI, Kalishwaralal K, Deepak V, Gracerosepat R, Srisakthi K, Gurunathan S. Biofilm inhibition and antimicrobial action of lipopeptide biosurfactant produced by heavy metal tolerant strain Bacillus cereus NK1. Colloids and Surfaces B: Biointerfaces, 2011; 85(2):174-181.

Thavasi R, Jayalakshmi S, Banat IM. Application of biosurfactant produced from peanut oil cake by Lactobacillus delbrueckii in biodegradation of crude oil. Bioresource Technology. 2011; 102:33663372

Van Hamme JD, Singh A, Ward OP. Physiological aspects Part 1 in a series of papers devoted to surfactants in microbiology and biotechnology. Biotechnology Advances, 2006; 24:604-620.

Yonebayashi H, Yoshida S, Ono K, Enomoto H, Screening of microorganisms for microbial enhanced oil recovery process. Sekiyu Gakkaishi, 2000; 43(1): 59-69.

Youssef NH, Duncan KE, Nagle DP, Savage KN, Knapp RM, McInerney MJ. Comparison of methods to detect biosurfactant production by diverse microorganisms. Journal of Microbiological Methods, 2003; 56:339- 347 .

Zgoła-Grześkowiak A, Kaczorek E. Isolation, preconcentration and determination of rhamnolipids in aqueous samples by dispersive liquid-liquid microextraction and liquid chromatography with tandem mass spectrometry. Talanta, 2011; 83(3):744-750.

Zhang Y, Miller RM. Effect of rhamnolipid (biosurfactant) structure on solubilization and biodegradation of n-alkanes. Appl Environ Microbiol, 1995; 61(6):2247-2251.

\section{How to cite this article:}

Meganathan Velmurugan, Athmanathan Baskaran, Subbaraj Dinesh Kumar, Indrajith Sureka, Edward Arockia Raj Jennifer Emelda , Karuppannan Sathiyamurthy. Screening, stability and antibacterial potential of rhamnolipids from Pseudomonas sp., isolated from hydrocarbon contaminated soil. J App Pharm Sci, 2015; 5 (08): 026-033. 